\title{
Outness among LGBTQ Social Work Students in North America: The Contribution of Environmental Supports and Perceptions of Comfort
}

\author{
Michael P. Dentato \\ Loyola University Chicago, mdentato@luc.edu \\ Shelley L. Craig \\ University of Toronto, shelley.craig@utoronto.ca \\ Lori Messinger \\ University of North Carolina - Wilmington, messingerl@uncw.edu \\ Michael Lloyd \\ Loyola University Chicago, mlloyd3@luc.edu \\ Lauren B. McInroy \\ University of Toronto, lauren.mcinroy@yahoo.ca
}

Follow this and additional works at: https://ecommons.luc.edu/social_justice

Part of the Social Work Commons

\section{Recommended Citation}

Dentato, Michael P.; Craig, Shelley L.; Messinger, Lori; Lloyd, Michael; and McInroy, Lauren B., "Outness among LGBTQ Social Work Students in North America: The Contribution of Environmental Supports and Perceptions of Comfort" (2013). Social Justice. 10.

https://ecommons.luc.edu/social_justice/10

This Article is brought to you for free and open access by the Centers at Loyola eCommons. It has been accepted for inclusion in Social Justice by an authorized administrator of Loyola eCommons. For more information, please contactecommons@luc.edu. 
This article was downloaded by: [Loyola University Libraries]

On: 18 November 2013, At: 12:18

Publisher: Routledge

Informa Ltd Registered in England and Wales Registered Number: 1072954 Registered

office: Mortimer House, 37-41 Mortimer Street, London W1T 3J H, UK

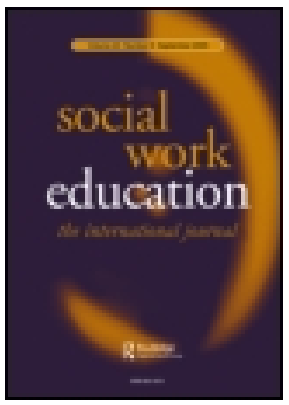

\title{
Social Work Education: The International J ournal
}

Publication details, including instructions for authors and subscription information:

http:// www.tandfonline.com/ loi/ cswe20

\section{Outness among LGBTQ Social Work Students in North America: The Contribution of Environmental Supports and Perceptions of Comfort}

\author{
Michael P. Dentato ${ }^{a}$, Shelley L. Craig ${ }^{b}$, Lori Messinger ${ }^{c}$, Michael \\ Lloyd $^{a} \&$ Lauren B. McInroy ${ }^{b}$ \\ a Michael P. Dentato \& Michael Lloyd, , Loyola University Chicago, \\ USA \\ ${ }^{b}$ Shelley L. Craig \& Lauren B. McInroy, , University of Toronto, \\ Canada \\ c Lori Messinger, , University of North Carolina Wilmington, USA. \\ Published online: 15 Nov 2013.
}

To cite this article: Michael P. Dentato, Shelley L. Craig, Lori Messinger, Michael Lloyd \& Lauren B. McInroy, Social Work Education (2013): Outness among LGBTQ Social Work Students in North America: The Contribution of Environmental Supports and Perceptions of Comfort, Social Work Education: The International J ournal, DOI: 10.1080/ 02615479.2013.855193

To link to this article: http:// dx.doi.org/ 10.1080/ 02615479.2013.855193

\section{PLEASE SCROLL DOWN FOR ARTICLE}

Taylor \& Francis makes every effort to ensure the accuracy of all the information (the "Content") contained in the publications on our platform. However, Taylor \& Francis, our agents, and our licensors make no representations or warranties whatsoever as to the accuracy, completeness, or suitability for any purpose of the Content. Any opinions and views expressed in this publication are the opinions and views of the authors, and are not the views of or endorsed by Taylor \& Francis. The accuracy of the Content should not be relied upon and should be independently verified with primary sources of information. Taylor and Francis shall not be liable for any losses, actions, claims, proceedings, demands, costs, expenses, damages, and other liabilities whatsoever or howsoever caused arising directly or indirectly in connection with, in relation to or arising out of the use of the Content. 
This article may be used for research, teaching, and private study purposes. Any substantial or systematic reproduction, redistribution, reselling, loan, sub-licensing, systematic supply, or distribution in any form to anyone is expressly forbidden. Terms \& Conditions of access and use can be found at http://www.tandfonline.com/page/termsand-conditions 


\title{
Outness among LGBTQ Social Work Students in North America: The Contribution of Environmental Supports and Perceptions of Comfort
}

\author{
Michael P. Dentato, Shelley L. Craig, Lori Messinger, \\ Michael Lloyd \& Lauren B. Mclnroy
}

This study examines various environmental factors that may impact a lesbian, gay, bisexual, transgender, or queer (LGBTQ) social work student's level of 'outness' (disclosure) with regard to their sexual orientation or gender identity. An internet-based survey was conducted, comprised of LGBTQ undergraduate and graduate students from social work programs across North America $(\mathrm{n}=1,018)$. Utilizing Pearson's chi square analysis, significant associations correlated between outness and the following six areas: (1) LGBTQ student perception of other students' overall level of comfort with their sexual orientation or gender identity within the program; (2) the number of faculty that know about their sexual orientation or gender identity; (3) the number of students that know about their sexual orientation or gender identity; (4) how supported they felt with regard to their LGBTQ identity within the program; (5) the percent of faculty that are supportive of $L G B$ and $Q$ issues; and (6) awareness of openly LGBTQ administrators or staff members. Implications for social work education and practice are examined, as are suggestions for continued research.

Keywords: Curriculum Development; Students; Profession; Diversity; Gay Issues; Lesbian Issues; Queer Issues; Sexuality; Transgender Issues; Quantitative Methods

\section{Background}

The level of 'outness' or disclosure with regard to sexual orientation and/or gender identity among lesbian, gay, bisexual, transgender, and queer (LGBTQ) students and faculty is critical to implicit learning within social work education (Bilodeau \& Renn,

\footnotetext{
Michael P. Dentato \& Michael Lloyd, Loyola University Chicago, USA; Shelley L. Craig \& Lauren B. McInroy, University of Toronto, Canada; Lori Messinger, University of North Carolina Wilmington, USA.

Correspondence to: Michael P. Dentato, School of Social Work, Loyola University Chicago, 820 North Michigan Avenue, \#1245, Chicago, IL 60611, USA. Tel.: 312-915-7030; Email: mdentato@luc.edu
} 
2005; Martin et al., 2009). Compared to privately remaining 'closeted' or not disclosing one's sexual orientation and/or gender identity, outness refers to the more public openness and expressiveness of such identities. Knoble and Linville (2012) describe outness as an important concept and core experience for members of the LGBTQ community. Evans and Broido (1999) examined contextual factors that influence the coming out experience, citing the level of perceived risk that may include physical or emotional harm, victimization, bullying or rejection from family, friends or faculty members, as a direct influence upon identity openness. Such contextual factors may differ based on race/ethnicity as evidenced by Moradi et al., who found differences regarding lower levels of outness among people of color when compared to their White counterparts, yet minimal significance when comparing levels of perceived heterosexist stigma, internalized homophobia, and concealment of sexual orientation (2010). The general challenges of being 'out' are well-documented regarding increased experiences of homophobia and stigma (Bonet, Wells, \& Parsons, 2007; Herek, 2007), victimization and bullying (Cox, Dewaele, Van Houtte, \& Vincke, 2010), increased family stress or crises (LaSala, 2000), and heightened risk of discrimination or harassment (Mohr, 1992; Rhoads, 1995), including such risk within workplace environments (Gates, 2011). The literature also provides examples of benefits to disclosing one's sexual identity including higher self-esteem and empowerment (Rasmussen, 2004), improved well-being (Clausell \& Roisman, 2009), and a newly gained sense of strength, courage, and resilience (Vaughan \& Waehler, 2010). Morris, Waldo, and Rothblum (2001) found that an inverse relationship existed between outness and psychological distress, as those more 'out' experienced less challenges and symptoms related to overall health and mental health, including decreased levels of suicidal ideation. Ultimately such disclosure decisions and level of outness may be best examined through the understanding of perceived consequences of coming out within specific environments, access to supportive colleagues, and evaluating the impact of stigma (Ragins, Singh, \& Cornwell, 2007). This study examines various environmental factors at the institutional, program, and classroom levels that may impact an LGBTQ social work student's level of outness with regard to their sexual orientation or gender identity.

\section{LGBTQ Identity Formation}

Identity formation is a key developmental task for all young adults, and there may be unique differences between LGBTQ and heterosexual identity development. Regardless, such identity formation typically occurs during high school and within collegiate environments (Evans \& Broido, 1999; Longerbeam, Inkelas, Johnson, \& Lee, 2007). The level of student outness likely coincides with stages of the LGBTQ identity formation process. Such identity formation is often described using linear stage models (Cass, 1984; Troiden, 1989), pertaining to sexual identity development. Cass defined six stages of gay identity development including: confusion; comparison; tolerance; acceptance; pride; and identity synthesis (1984). Troiden examined four chronological stages of identity development including: sensitization; identity 
confusion; identity assumption; and commitment. D'Augelli's (1994) lifespan model of identity formation offers an alternative to the stage models, positing a more fluid and multi-dimensional pathway to coming out. Notably, Bilodeau and Renn (2005) expand upon these models to incorporate transgender identity development. Savin-Williams and Diamond (2000) note that gender differences may exist between awareness and disclosure, whether in grade school, high school, or college, providing diverse opportunities for LGBTQ youth to develop and explore identity formation related to sex, sexuality, sexual orientation, gender identity, and gender expression. While being out about one's sexual orientation and/or gender identity is not explicitly referenced in Cass's stages of identity acceptance and identity pride, nor in D'Augelli's identity process of exiting heterosexuality, all implicitly refer to the concept and process of outness and disclosure for LGBTQ individuals. Exploring the impact of intersectionality related to class, gender, and sexuality (Taylor, 2009) along with other sociodemographic factors, may assist with a clearer understanding of the coincidence or likelihood of outness and correlation with the pathway of LGBTQ identity formation.

\section{Outness in Social Work Programs}

Some LGBTQ social work students attending undergraduate or graduate programs may enter such programs as 'out' individuals with regard to their sexual orientation and/or gender identity, while others may choose to remain closeted or not come out during their tenure within such programs. Such varied levels of outness may or may not be related to the students' stage of identity development in the ongoing coming out process (Evans \& D’Augelli, 1996; Rhoads, 1995, 1997; Stevens, 2004). Along with examining the impact of identity formation on outness, myriad factors related to institutional (Gates, 2011; Ragins et al., 2007) and classroom environments (Ben-Ari, 2001), perceptions of safety, comfort, support (Herek, 2004, 2007; Hines, 2012), and inclusion may also hold significant relevance for understanding the process of LGBTQ social work student disclosure surrounding sexual orientation and/or gender identity.

\section{Institutional factors}

Various factors may impact a student's level of outness in institutional, classroom, and field environments. Support and advocacy within each of these unique environments are key to positively influencing identity formation and the decision to disclose, as well as impact the fulfillment of broader developmental and educational tasks (Messinger, 2011). Key factors for increasing LGBTQ inclusiveness on campuses identified by Rankin (2005) include increased sensitivity in various facets of student life and providing institutional support through social outlets, housing, and supportive policies which can ultimately affect LGBTQ social work student outness. In the same regard, Zemsky and Sanlo (2005) identify the benefits of anti-discrimination policies and their effects on LGBT faculty and staff to disclose their sexual orientation publicly 
without overtly risking their jobs (Ragins et al., 2007), academic advancement, or professional standing (Gates, 2011).

Waldo (1998) discusses the global campus atmosphere as having an impact upon LGBT student identity formation and increased levels of anxiety and hostility, noting that LGBT students often receive support from within their own community, yet are often negatively affected by a less accepting campus environment. Westbrook (2009) underscores the importance of campus community centers and specific spaces for LGBTQ students, fostering discourse among fellow LGBTQ students and allies, as well as providing safe and supportive spaces. D’Augelli (1992) discusses the existence of LGBT student organizations and courses offered in LGBT studies, exploring how some institutions have hired staff specifically designated to work with LGBT campus communities. Regardless, while progress has been made and some university environments are relatively supportive of LGBTQ students, heterosexism and homophobia may prevail or often be minimized (Fine, 2011; Rankin, 2003, 2005) rather than countered with support. While institutional environment and non-discrimination policies can be explored further at the macro-level, the classroom environment affects LGBTQ social work students at the micro-level.

\section{Classroom experiences}

As the college classroom is often central to the LGBTQ student experience (Longerbeam et al., 2007), classmates and instructors can positively and negatively impact student participation and the overall classroom environment. Classrooms were identified as hostile when homophobic behaviors, attitudes, and messages came from instructors and students alike, ultimately resulting in a negative impact upon the overall learning experience. Conversely, the most supportive LGBTQ student environments included those where LGBTQ issues and perspectives were an integral part of the curriculum, through inclusion of readings, videos, or guest speakers (Longerbeam et al., 2007).

\section{Faculty outness}

Openly out faculty, staff, and administrators can positively influence LGBTQ social work students (Cain, 1996; D’Emilio, 1987; Donadello, 1986; Gates, 2011; Messinger, 2011). Hylton (2005) found that faculty disclosure of sexual identity often benefits their LGBTQ students, as 'out' faculty become invaluable resources and supportive role models. An instructor's outness and curricular efforts can underscore support and inclusiveness for LGBTQ students within schools (Cain, 1996), while also providing a mentoring relationship (Lark \& Croteau, 1998). Such mentors fulfill a vital role in modeling for their students the 'possible self' in an environment of safety and inclusiveness (Lark \& Croteau, 1998) as well as effectively demonstrating the intersection of personal and professional (Gates, 2011). While Ben-Ari (2001) found low levels of homophobia in a study of academics in social work compared to those in the field of education, faculty should ensure a 'safe' classroom environment for expression of personal experiences and diversity, while promoting student safety 
(Graham-Smith \& Lafayette, 2004). Thus, factors such as non-discrimination policies; the number of 'out' faculty and/or 'out' students; LGBTQ-friendly student clubs and organizations; or public/private spaces for socialization, have been shown to positively influence the overall LGBTQ student experience (Lipka, 2011; Messinger, 2011; Rankin, 2003, 2005).

There is a lack of research regarding factors specifically related to the coming out experience of social work students and whether there is institutional support within such environments (Logie, Bridge, \& Bridge, 2007; Van Den Berg \& Crisp, 2004). To address this gap, this study specifically examines associations between LGBTQ social work students' level of outness and perceptions of non-LGBTQ student support; the impact of LGBTQ student outness among faculty, administrators, and other students; awareness of 'out' LGBTQ faculty, administrators, and other students; perceptions of support for a student's LGBTQ identity, along with other university, school, and program environmental factors that may impact their overall experience.

\section{Methods}

An online survey of social work students in North America was conducted during a 10-week period from April through to June 2012. An introductory email was distributed to each Bachelor of Social Work (BSW) or Master of Social Work (MSW) program in the United States and Canada accredited by the Council on Social Work Education (CSWE) and the Canadian Association for Social Work Education (CASWE). The email invitation was sent twice to the deans/directors of each social work school, department, or program, as well as directly to various student listservs. Additional email invitations to participate were posted on major disciplinary listservs including: Association of Baccalaureate Social Work Program Directors (BPD); National Association of Deans and Directors of Schools of Social Work (NADD); Group for the Advancement of Doctoral Education in Social Work (GADE); and the LGBT Social Work Caucus, among others. Inclusion criteria consisted of: (1) college education; (2) age 18 or older; (3) current enrollment in a BSW or MSW program; (4) identification as lesbian, gay, bisexual, transgender, or queer; and (5) fluency in English.

Following informed consent procedures, students responded to a series of 82 questions related to their experience within their respective schools and programs, generally completing the survey in a 30-minute time frame. Upon completion of the survey, participants were offered the option of providing their email address to enter a draw for a \$20 gift card from an internet-based retailer. Survey participants were encouraged to contact the primary investigator via email with any questions or concerns related to survey completion. The study was jointly approved via IRB ethics protocols associated with the primary (\#1037) and secondary (\#27208) author's institutions (Craig, Dentato, Messenger, \& McInroy, Under Review).

In addition to capturing sociodemographic information related to each of the participants and the schools attended (optional), the survey consisted of questions 
regarding the institution, the social work program and their educational experiences. Student level of outness was measured as 'very out', 'somewhat out', and 'not out at all'. The 'do not know' and 'missing' categories were insignificant and therefore omitted for analyses. Additional questions that were the focus of this study related to: the impact of LGBTQ student outness among faculty, administrators, and other students; awareness of 'out' LGBTQ faculty, administrators, and other students; perceptions related to support for their identity; and perceptions of other students' comfort with their various levels of outness regarding sexual orientation and/or gender identity.

The survey was comprised of a number of question types, including multiple choice questions with a four- or six-point Likert scale, generally including an open-ended response option, as well as a series of open-ended questions. Categorical variables utilized a 'yes/no' format, though a 'do not know' or 'unsure' option was typically included. For the purpose of this analysis, the 'unsure' categories were collapsed or omitted due to size, and asexual, questioning, and straight participants were collapsed into the 'other' sexual orientation category. There was little missing data, with a range from 0 to $3 \%$ on retained variables. Missing data were imputed using a multiple imputation approach.

\section{Participant Demographics}

Respondents to the Social Work Students Speak Out survey $(n=1,310)$ identified themselves as BSW $(n=243)$ or MSW $(n=771)$ students and a total of 1,018 responded as LGBTQ. The majority of participants surveyed were 29 and under $(n=597)$ and identified as female $(n=737)$, male $(n=217)$, or trans-identified $(n=62)$. A majority identified their sexual orientation as lesbian $(n=305)$, bisexual $(n=257)$, gay $(n=174)$, and queer $(n=168)$. Race/ethnicity was reported as: White, non-Hispanic $(n=759)$; White, Hispanic $(n=77)$; Black, non-Hispanic $(n=53)$; and Black, Hispanic $(n=23)$, among others (Table 1$)$.

\section{Analysis}

To examine the relationship between the level of students' outness related to their sexual orientation and/or gender identity and their experiences within their universities, schools, and programs, the Pearson chi-square test of association was used to test the statistical significance of these bivariate relationships. The dependent variable, defined as a student's level of outness ('very out', 'somewhat out', 'not out at all'), was compared to the independent variables defined by the three categories of questions in the survey, namely: institutional environment (e.g. size of program, religious affiliation, nondiscrimination policies, student organizations, groups, clubs, lounges, mentoring programs, gender-neutral bathrooms); the social work program environment (e.g. nondiscrimination policies, student organizations, groups, clubs, lounges, mentoring programs); and those questions related to the student's personal experiences within the social work program (e.g. perception of other students' level of comfort with LGBTQ 
Table 1 Participant Demographics $(n=1,018)$

\begin{tabular}{|c|c|c|}
\hline Characteristic & $\mathrm{n}$ & $\%$ \\
\hline \multicolumn{3}{|l|}{ Gender $(\mathrm{n}=1,017)$} \\
\hline Female & 737 & 72.5 \\
\hline Male & 217 & 21.3 \\
\hline No gender categories & 49 & 4.8 \\
\hline Trans man & 29 & 2.9 \\
\hline Other transgender & 25 & 2.5 \\
\hline Trans woman & 8 & 0.8 \\
\hline \multicolumn{3}{|l|}{ Age $(\mathrm{n}=1,017)$} \\
\hline 29 and under & 597 & 58.7 \\
\hline $30-39$ & 253 & 24.9 \\
\hline $40-49$ & 107 & 10.5 \\
\hline $50-59$ & 50 & 4.9 \\
\hline 60 and over & 10 & 1 \\
\hline \multicolumn{3}{|l|}{ Sexual orientation $(\mathrm{n}=1,018)$} \\
\hline Lesbian & 305 & 30 \\
\hline Bisexual & 257 & 25.2 \\
\hline Gay & 174 & 17.1 \\
\hline Queer & 168 & 16.5 \\
\hline Other & 62 & 6.1 \\
\hline Pansexual & 52 & 5.1 \\
\hline \multicolumn{3}{|l|}{ Race \& ethnicity $(\mathrm{n}=1,012)$} \\
\hline White, non-Hispanic & 759 & 75 \\
\hline White, Hispanic & 77 & 7.6 \\
\hline Multi-racial & 56 & 5.5 \\
\hline Black, non-Hispanic & 53 & 5.2 \\
\hline Asian/Pacific Islander & 27 & 2.7 \\
\hline Black, Hispanic & 23 & 2.3 \\
\hline Hispanic, no race provided & 10 & 1 \\
\hline Other & 7 & 0.7 \\
\hline \multicolumn{3}{|l|}{ Parent education $(\mathrm{n}=1,015)$} \\
\hline Less than middle school & 17 & 1.7 \\
\hline Middle school & 25 & 2.5 \\
\hline High School & 247 & 24.3 \\
\hline Community college / vocational school & 156 & 15.4 \\
\hline University / college & 264 & 26 \\
\hline Advanced degree & 306 & 30.1 \\
\hline
\end{tabular}

counterparts, faculty and student awareness of LGBTQ students, perceptions of support, awareness of out/closeted administrators, faculty, and students).

\section{Results}

\section{Level of Outness}

Results of the three categories corresponding with levels of student outness regarding sexual orientation and/or gender identity included: 'very out' ( $n=442,43 \%)$; 'somewhat out' ( $n=458,45 \%)$; and 'not out' $(n=112,11 \%)$. 


\section{Institutional Environment}

Most participants $(n=694,68 \%)$ had knowledge of existing non-discrimination policies addressing sexual orientation, while some 'did not know' ( $n=310,30 \%)$. Conversely, some participants $(n=384,38 \%)$ had knowledge of existing nondiscrimination policies addressing gender identity, while many 'did not know' ( $n=543$, $53 \%$ ). Reponses related to knowledge of existing LGBTQ organizations or student groups were mostly favorable $(n=891,87 \%)$, while knowledge related to an existing LGBTQ student center or lounge were almost equally divided between: 'yes' ( $n=397,39 \%)$, 'no' ( $n=337,33 \%)$, and 'do not know' $(n=281,28 \%)$. Similarly, knowledge of LGBTQ mentoring programs resulted in a majority that 'did not know' $(n=584,57 \%)$ and most students reported no existing unisex or gender-neutral bathrooms ( $n=571,56 \%)$.

\section{Social Work Program Environment}

A majority $(n=585,57 \%)$ reported their social work program had a nondiscrimination policy associated with sexual orientation. Most responded that they 'did not know' about a non-discrimination policy associated with gender identity $(n=527$, $52 \%)$, as compared to those responding 'yes' $(n=411,40 \%)$. Reponses related to existing social work program specific LGBTQ organizations or student groups included those that reported 'no' $(n=562,55 \%)$ and 'yes' $(n=306,30 \%)$. Results of knowledge related to an existing social work program specific LGBTQ student center or lounge included a majority of 'no' ( $n=888,87 \%)$; and similarly, LGBTQ mentoring programs resulted in a majority of students responding 'no' $(n=685,67 \%)$.

Results demonstrated no strong associations with level of student outness and university or school non-discrimination policies, size of the institution, religious/ non-religious institutional affiliation, or the presence of LGBTQ clubs or spaces. However significant associations were found among the following six categories: (1) LGBTQ student perception of other students' overall level of comfort with their sexual orientation and/or gender identity within the program; (2) how many faculty know about their sexual orientation and/or gender identity; (3) how many students know about their sexual orientation and/or gender identity; (4) how supported they felt with regard to their LGBTQ identity within the program; (5) percent of faculty that are supportive of LGB and Q issues; and (6) awareness of openly LGBTQ administrators or staff members. In each of the six aforementioned categories, there was a statistically significant correlation $(p<0.001)$ between a student's level of outness and the corresponding independent variable (Tables 2-7).

\section{Associations of LGBTQ Student Level of Outness with Environment and Experience}

LGBTQ student perception of other students' overall level of comfort

The association of LGBTQ students' perception of non-LGBTQ students' overall level of comfort related to their level of outness follows: $c^{2}(4, n=911)=46.0$, 
Table 2 Level of Outness Related to Other Students Overall Level of Comfort $(n=911)$

n (actual)

(\% within out category) Very comfortable Somewhat comfortable Not comfortable Total

\begin{tabular}{lcccc}
\hline Very out & $228(56)$ & $195(42)$ & $11(29)$ & $434(47)$ \\
Somewhat out & $152(37)$ & $251(54)$ & $18(47)$ & $421(46)$ \\
Not out & $26(6)$ & $21(4)$ & $9(24)$ & $56(6)$ \\
Total & $406(99)$ & $467(100)$ & $38(100)$ & $911(99)$
\end{tabular}

Table 3 Level of Outness Related to Faculty Awareness of Sexual Orientation and/or Gender Identity $(n=1,010)$

n (actual)

(\% within out category) All faculty Most faculty Some faculty Few faculty No faculty Total

\begin{tabular}{|c|c|c|c|c|c|c|}
\hline Very out & $126(93)$ & $188(76)$ & $97(41)$ & $22(10)$ & $9(5)$ & $442(44)$ \\
\hline Somewhat out & $8(6)$ & $56(23)$ & $134(57)$ & $174(79)$ & $85(48)$ & $457(45)$ \\
\hline Not out & $1(0.7)$ & $2(0.8)$ & $3(1)$ & $24(11)$ & $81(46)$ & $111(11)$ \\
\hline Total & $135(100)$ & $246(100)$ & $234(100)$ & $220(100)$ & $175(100)$ & $1010(100)$ \\
\hline
\end{tabular}

Table 4 Level of Outness Related to Other Students' Awareness of Sexual Orientation and/or Gender Identity $(n=1,011)$

\begin{tabular}{|c|c|c|c|c|c|c|}
\hline $\begin{array}{l}\mathrm{n}(\text { actual }) \\
(\% \text { within out category })\end{array}$ & $\begin{array}{l}\text { All } \\
\text { students }\end{array}$ & $\begin{array}{c}\text { Most } \\
\text { students }\end{array}$ & $\begin{array}{c}\text { Some } \\
\text { students }\end{array}$ & $\begin{array}{c}\text { Few } \\
\text { students }\end{array}$ & $\begin{array}{l}\text { No } \\
\text { students }\end{array}$ & Total \\
\hline Very out & $173(94)$ & $217(66)$ & $43(17)$ & $6(3)$ & $3(4)$ & $442(44)$ \\
\hline Somewhat out & $10(5)$ & $108(33)$ & $201(81)$ & $131(75)$ & $7(9)$ & $457(45)$ \\
\hline Not out & $1(0.5)$ & $2(0.6)$ & $5(2)$ & $38(22)$ & $66(87)$ & $112(11)$ \\
\hline Total & $184(100)$ & $327(100)$ & $249(100)$ & $175(100)$ & $76(100)$ & $1011(100)$ \\
\hline
\end{tabular}

Table 5 Level of Outness Related to How Supported They Felt with Regard to Their LGBTQ Identity $(n=973)$

\begin{tabular}{|c|c|c|c|c|c|c|}
\hline $\begin{array}{l}\mathrm{n}(\text { actual }) \\
\text { (\% within out category) }\end{array}$ & $\begin{array}{c}\text { Very } \\
\text { supported }\end{array}$ & $\begin{array}{l}\text { Somewhat } \\
\text { supported }\end{array}$ & Neutral & $\begin{array}{c}\text { Somewhat } \\
\text { not supported }\end{array}$ & $\begin{array}{c}\text { Not } \\
\text { supported } \\
\text { at all }\end{array}$ & Total \\
\hline Very out & $215(63)$ & $133(43)$ & $61(31)$ & $20(23)$ & $7(16)$ & $436(45)$ \\
\hline Somewhat out & $114(34)$ & $163(53)$ & $102(52)$ & $51(60)$ & $19(44)$ & $449(46)$ \\
\hline Not out & $10(3)$ & $13(4)$ & $34(17)$ & $14(16)$ & $17(39)$ & $88(9)$ \\
\hline Total & $339(100)$ & $309(100)$ & $309(100)$ & $85(100)$ & $43(100)$ & $973(100)$ \\
\hline
\end{tabular}

Table 6 Level of Outness Related to Percent of Faculty that are Supportive of LGBQ Issues $(n=914)$

\begin{tabular}{lccccc}
\hline $\mathrm{n}$ (actual) (\% within out category) & $0-25 \%$ & $26-50 \%$ & $51-75 \%$ & $76-100 \%$ & Total \\
\hline Very out & $9(23)$ & $29(41)$ & $81(40)$ & $294(49)$ & $413(45)$ \\
Somewhat out & $21(54)$ & $32(46)$ & $99(48)$ & $250(42)$ & $402(44)$ \\
Not out & $9(23)$ & $9(13)$ & $24(12)$ & $57(9)$ & $99(11)$ \\
Total & $39(100)$ & $70(100)$ & $204(100)$ & $601(100)$ & $914(100)$
\end{tabular}


Table 7 Level of Outness Related to Awareness of Openly LGBTQ Administrators or Staff $(n=927)$

\begin{tabular}{lccc}
\hline $\mathrm{n}$ (actual) (\% within out category) & Yes & No & Total \\
\hline Very out & $174(54)$ & $233(38)$ & $407(44)$ \\
Somewhat out & $122(38)$ & $295(48)$ & $417(45)$ \\
Not out & $23(7)$ & $80(13)$ & $103(11)$ \\
Total & $319(100)$ & $608(100)$ & $927(100)$ \\
\hline
\end{tabular}

$p=0.000-\chi^{2}(4)=46.00, p<0.001$. Please note that results are reported as the number of participant responses followed by the associated percent within the corresponding category. Participants were asked about their perceptions of other students' level of comfort resulting in a majority of 'very out' students reporting 'very comfortable' $(n=228,56 \%)$ and 'somewhat out' students reporting 'somewhat comfortable' $(n=251,54 \%)$ and 'not comfortable' $(n=18,47 \%)$ (Table 2).

LGBTQ student perception of faculty knowledge of their sexual orientation and/or gender identity

The association of students' reporting faculty knowledge related to their level of outness of sexual orientation and/or gender identity follows: $c^{2}$ $(8, n=1,010)=644.724, p=0.000-\chi^{2}(8)=644.724, p<0.001$. Some $71 \%$ of responses from students who were 'very out' reported that all $(n=126,93 \%)$ or most $(n=188,76 \%)$ faculty knew the student's sexual orientation and/or gender identity. In contrast, those students 'somewhat out' reported some $(n=134,57 \%)$ or few $(n=174,79 \%)$ faculty were aware of their sexual orientation and/or gender identity, with almost three-quarters of those students who are 'not out' reporting no faculty $(n=81,46 \%)$ were aware of their sexual orientation and/or gender identity (Table 3).

LGBTQ student perception of non-LGBTQ student knowledge of sexual orientation and/ or gender identity

The association of students' reporting other students' awareness related to their level of outness of sexual orientation and/or gender identity follows: $c^{2}(8$, $n=1,011)=958.512, p=0.000-\chi^{2}(8)=958.512, p<0.001$. The majority of responses from students who were 'very out' reported that all $(n=173,94 \%)$ or most $(n=217,66 \%)$ other students were aware of their sexual orientation and/or gender identity. In contrast, those students who were 'somewhat out' reported some $(n=201$, $81 \%)$ or few $(n=131,75 \%)$ other students were aware of their sexual orientation and/ or gender identity. For those 'not out', the majority reported that few $(n=38,22 \%)$ or no $(n=66,87 \%)$ other students were aware of their sexual orientation and/or gender identity (Table 4). 
How supported they felt with regard to their LGBTQ identity

The association of students' reporting the level of support they felt with regard to their LGBTQ identity within their social work program follows: $c^{2}(8, n=973)=156.606$, $p=0.000-\chi^{2}(8)=156.606, p<0.001$. The majority of responses from students who were 'very out' felt 'very supported' $(n=215,63 \%)$. 'Somewhat out' students felt 'somewhat supported' $(n=163,53 \%)$ or 'neutral' support $(n=102,52 \%)$ with regard to their LGBTQ identity. In contrast, associations for those students who were 'not out' felt 'not supported' $(n=17,39 \%)$, 'somewhat not supported' $(n=14$, $16 \%)$, or 'neutral' support $(n=34,17 \%)$ with regard to their sexual orientation and/ or gender identity (Table 5 ).

\section{Percent of faculty that are supportive of $L G B$ and $Q$ issues}

The association of students' reporting faculty supportive of lesbian, gay, bisexual, and queer issues within the social work program follows: $c^{2}$ $(6, n=914)=17.129, p=0.000-\chi^{2}(6)=17.129, p<0.001$. The majority of responses from students who were 'very out' indicated that between $76 \%$ and $100 \%(n=294,49 \%)$ of faculty are supportive of LGBQ issues. In contrast, those students who were 'somewhat out' reported that between $51 \%$ and $75 \%(n=99$, $48 \%$ ) of faculty are supportive of LGBQ issues. Those students 'not out' indicated that between $51 \%$ and $75 \%(n=24,12 \%)$ and $76 \%$ and $100 \%(n=57,9 \%)$ of faculty are supportive of LGBQ issues. Notably, there was no strong association in this study related to student perceptions of faculty support for transgender issues (Table 6).

\section{Awareness of openly LGBTQ administrators and staff}

The association of students' reporting awareness of openly LGBTQ administrators or staff members within their social work program follows: $c^{2}(2, n=927)=24.114$, $p=0.000-\chi^{2}(2)=24.114, p<0.001$. Most 'very out' students were not aware of openly LGBTQ administrators and staff $(n=233,38 \%)$. Similarly, 'somewhat out' students $(n=295,48 \%)$ or 'not out' students $(n=80,13 \%)$ were not aware of openly LGBTQ administrators and staff (Table 7).

\section{Discussion}

Findings from this study add significantly to our understanding of the role of educational factors that contribute to outness among LGBTQ social work students. Key findings from this study underscore significant relationships between a student's level of outness and environmental factors, including perceptions of non-LGBTQ students' level of comfort, faculty and other student knowledge about the LGBTQ students' identities, perceptions of support for their identity, faculty support for sexual orientation issues, and LGBTQ students' awareness of openly LGBTQ administrators and staff members. 


\section{Reciprocal Outness}

A student's level of outness with regard to their sexual orientation and/or gender identity may impact upon perceptions of comfort among self and others. This may be best understood as a reciprocal model through which the amount of non-LGBTQ student support may be reliant upon the level of the LGBTQ student's outness and vice versa. In the same regard, those students in this study who reported a lack of perceived comfort from other students were more likely to be somewhat out or not out at all. Evans and Broido (1999) identified that perceptions of risk strongly influence a student's comfort with coming out in various environments. As such, one's level of outness and perceptions of comfort may support positive identity acceptance. Research on identity formation (Cass, 1984; D’Augelli, 1989; Troiden, 1993) underscores the importance of identity acceptance and identity disclosure.

\section{Internal and External Factors}

The findings in this study point to the relationship between internal and external factors related to LGBTQ students' disclosure of their sexual orientation and/or gender identity. Participants were more likely to be 'very out' or 'somewhat out' among other students rather than faculty members. Student-to-student comfort is one important aspect that may affect outness, yet it is not the only impactful relationship for LGBTQ students. As expected, a student's level of outness may increase overall faculty awareness related to LGBTQ issues (i.e. the more a social work student is 'out' increases faculty awareness; may influence faculty acceptance; and hopefully extend supportive systems). However, it may be important to understand the implications for those that remain closeted and myriad factors that impact a student's decision to disclose within their program. Openly 'out' LGBTQ faculty, administrators, or staff, as well as potential peer allies, offer an indication of safety and openness for LGBTQ students in social work programs, while simultaneously modeling and affording an opportunity to develop individual 'wholeness' (Gates, 2011). Messinger (2011) found that 'out' faculty members were better able to advocate for themselves as well as their students, and they can increase visibility while supporting students who may still be deciding about whether or not to come out. Oppositely, it is plausible that students that are more 'out' than faculty members could be encouraging such faculty to come out through their advocacy and openness.

\section{LGBTQ identity formation, attachment and outness}

Ongoing challenges remain with regard to a comprehensive understanding of the factors impacting an LGBTQ student's identity development, perceptions of comfort and need for unconditional acceptance. While researchers have previously identified the importance of relationships and environmental factors that may impact on development utilizing the lens of attachment theory, such assessment may be helpful when understanding LGBTQ identity development and level of outness among study participants. For example, Bartholomew and Horowitz (1991) explore fearful/ 
avoidant attachment styles which combine a sense of unworthiness with an expectation that others will be untrustworthy. The findings of this study may indicate that a lack of close and supportive contacts can influence the decision-making process related to coming out or remaining closeted, perceptions of comfort with self and others, and ultimately influence identity developmental processes. Continued examination related to the intersecting roles of LGBTQ identity formation and various levels of student outness may be crucial to understanding within field settings to ensure a holistic and supportive student experience (Messinger, 2004). Thus, LGBTQ social work students should experience a consistent, meaningful, and supportive environment throughout their respective institutions, social work programs, classrooms, and field experiences.

Ultimately, such environments that are more inclusive of LGBTQ issues and sensitive to the diverse needs of LGBTQ students have the potential to assist such students with their own well-being (Gates, 2011), positive growth, and identity acceptance. Waldo (1999) found that experiences of heterosexism within specific environments could lead to adverse outcomes or distress, consistent with Meyer's minority stress theory (1995) underscoring the association of unique stressful experiences and one's minority status. Exploring the political and sociohistorical contexts of such environments may assist with understanding unique influences upon student outness and visibility (Bilodeau \& Renn, 2005). Additionally, the examination of an anti-oppressive practice framework may further underscore the role of environmental influences including institutional, economic, cultural, and personal influences upon a student's identity, level of outness and overall ability to flourish within oppressive contexts (Hines, 2012). Faculty and student awareness of, and sensitivity toward, LGBTQ issues within the institutional, classroom, and field environments may support LGBTQ students with the coming out process, increase feelings of safety within those environments, and diminish homophobia, transphobia, and heterosexism. To further eradicate homophobia and heterosexism from such environments, we must examine the definitions and impact of alternative terminologies, including sexual prejudice and sexual stigma (Herek, 2004). The impact of understanding and confronting such stigma, whether 'felt', 'enacted', or 'internalized' (Herek, 2007), clearly holds implications for educators and practitioners alike.

The findings of this study further the idea that perceptions of faculty support for LGB and Q issues may differ based on level of student outness. While these findings are not surprising, there remains room for continued investigation with regard to the need of such support specifically with regard to transgender and gender variant students. Notably, there were a relatively small proportion of trans-identified study participants, which may have diminished the significance of support for transgender students as well as the amount of transphobia reported. Continued research in this area may hold implications related to the level of perceived comfort with coming out within one's social work program as well as accessing supportive services. Those that were not out felt less support within their programs, which may highlight the need for the creation of program environments which include infusion of LGBTQ curricular content, 
non-discrimination policies, student groups, spaces, etc. The level of perceived support among LGBTQ students may impact their overall program or classroom experience, and ultimately, their preparedness to work with diverse communities (Craig et al., Under Review) including LGBTQ individuals.

\section{Limitations}

There are several limitations of this study that should be noted. The first relates to the racial/ethnic and gender composition of the study population which was predominantly White, Non-Hispanic, and female, with a relatively low number of racial/ethnic minority and male student respondents. This study did not specifically recruit racial/ethnic minority populations; however, the underrepresentation of racial/ ethnic minorities may be found in many social work programs (CSWE, 2012, 2013). In the same regard, the underrepresentation of male students within social work programs may be reflective of a larger trend found within social work education (CSWE, 2009) as well. Study participants without internet access or comfort with online recruitment methods would not have been able to participate, while students inconsistently checking email, not responding to listserv emails, or preferring social media sites over email formats, may have been other factors limiting survey responses. Furthermore, this study may not be fully representative of all LGTBQ students in social work programs throughout North America, regardless of the varied recruitment efforts. This study does not reflect the experiences of all BSW or MSW students, as well as doctoral students or those attending social work programs outside of the data collection period. Analysis of a student's level of outness with regard to their sexual orientation and/or gender identity is limited to those students who responded to survey questions and does not completely demonstrate myriad personal associations, meanings, or definitions of outness. However, despite such limitations, this study adds to the literature a greater understanding of environmental factors that may impact an LGBTQ social work student's outness and perceptions of comfort, while lending important explicit and implicit opportunities for social work education from the university level to classroom experiences alike.

\section{Conclusion}

Social work education requires continual reflexivity and authenticity as noted throughout the profession's history, values, and ethics. Administrators and educators must remain attuned to the needs of all diverse student populations, whether by advocating for inclusive policies, monitoring the integration of LGBTQ issues throughout the curriculum, or ensuring a globally welcoming and affirming atmosphere. Ultimately, to monitor and improve upon the various facets of such an inviting campus climate for LGBTQ social work students, whether at the institutional or classroom level, an active and transformative position is required (Rhoads, 1995, 1997), rather than responding through reactive efforts. In the same regard, ongoing advocacy efforts should be maintained for all minority populations, including LGBTQ 
social work students to ensure an affirming experience at the undergraduate, graduate, and doctoral levels alike.

\section{References}

Bartholomew, K., \& Horowitz, L. M. (1991). Attachment styles among young adults: A test of a fourcategory model. Journal of Personality and Social Psychology, 61, 226-244.

Ben-Ari, A. T. (2001). Homosexuality and heterosexism: Views from academics in the helping professions. British Journal of Social Work, 31, 119-131.

Bilodeau, B. L., \& Renn, K. A. (2005). Analysis of LGBT identity development models and implications for practice. New Directions for Student Services, 11, 25-39.

Bonet, L., Wells, B. E., \& Parsons, J. T. (2007). A positive look at a difficult time: A strength based examination of coming out for lesbian and bisexual women. Journal of LGBT Health Research, 3, 7-14.

Cain, R. (1996). Heterosexism and self-disclosure in the social work classroom. Journal of Social Work Education, 32, 65-76.

Cass, V. C. (1984). Homosexual identity formation: Testing a theoretical model. The Journal of Sex Research, 20, 143-167.

Clausell, E., \& Roisman, G. I. (2009). Outness, big five personality traits, and same-sex relationship quality. Journal of Social and Personal Relationships, 26, 211-226.

Council on Social Work Education [CSWE]. (2009). Toolkit on recruitment \& retention of historically underrepresented faculty and doctoral students in social work education. Council on Racial, Ethnic and Cultural Diversity (CRECD). Retrieved August 4, from http://www.cswe.org/File. aspx?id $=49345$

Council on Social Work Education [CSWE]. (2012). 2011 Statistics on Social Work Education. Retrieved August 19, 2013, from http://www.cswe.org/File.aspx?id=62011

Council on Social Work Education [CSWE]. (2013). Accreditation Report. Retrieved August 19, 2013, from http://www.cswe.org/Accreditation.aspx

Cox, N., Dewaele, A., Van Houtte, M., \& Vincke, J. (2010). Stress-related growth, coming out, and internalized homonegativity in lesbian, gay, and bisexual youth. An examination of stressrelated growth within the minority stress model. Journal of Homosexuality, 58, 117-137.

Craig, S. L., Dentato, M. P., Messinger, L., \& McInroy, L. (Under Review). Educational determinants of readiness to practice with LGBTQ clients: Social work students speak out. British Journal of Social Work.

D’Augelli, A. R. (1989). Lesbians' and gay men's experiences of discrimination and harassment in a university community. American Journal of Community Psychology, 17, 317-321.

D'Augelli, A. R. (1992). Lesbian and gay male undergraduates' experiences of harassment and fear on campus. Journal of Interpersonal Violence, 7, 383-395.

D’Augelli, A. R. (1994). Identity development and sexual orientation: Toward a model of lesbian, gay, and bisexual development. In E. J. Trickett, R. J. Watts, \& D. Birman (Eds.), Human diversity: Perspectives on people in context (pp. 312-333). San Francisco, CA: Jossey-Bass.

D’Emilio, J. (1987). Homosexual professors owe it to their students to come out. Chronicle of Higher Education, 28, A52.

Donadello, G. (1986). Integrating lesbian/gay male experience in feminist practice and education. In N. Van Den Bergh \& L. B. Cooper (Eds.), Feminist visions for social work (pp. 283-298). Silver Spring, MD: National Association of Social Workers.

Evans, N. J., \& Broido, E. M. (1999). Coming out in college residence halls: Negotiation, meaning making, challenges, supports. Journal of College Student Development, 40, 658-668. 
Evans, N. J., \& D’Augelli, A. R. (1996). Lesbians, gay men, and bisexual people in college. In R. C. Savin-Williams \& K. M. Cohen (Eds.), The lives of lesbians, gays, and bisexuals: Children to adults (pp. 201-226). Fort Worth, TX: Harcourt Brace College.

Fine, L. E. (2011). Minimizing heterosexism and homophobia: Constructing meaning of out campus LGB life. Journal of Homosexuality, 58, 521-546.

Gates, T. G. (2011). Coming out in the social work classroom: Reclaiming wholeness and finding the teacher within. Social Work Education, 30, 70-82.

Gates, T. G. (2011). Why employment discrimination matters: Well-being and the queer employee. Journal of Workplace Rights, 16, 107-128.

Graham-Smith, S., \& Lafayette, S. (2004). Quality disability support for promoting belonging and academic success within the college community. College Student Journal, 38, 90.

Herek, G. M. (2004). Beyond "Homophobia": Thinking about sexual prejudice and stigma in the twenty-first century. Sexuality Research \& Social Policy: Journal of NSRC, 1, 6-24.

Herek, G. M. (2007). Confronting sexual stigma and prejudice: Theory and practice. Journal of Social Issues, 63, 905-925.

Hines, J. M. (2012). Using an anti-oppressive framework in social work practice with lesbians. Journal of Gay \& Lesbian Social Services, 24, 23-39.

Hylton, M. E. (2005). Heteronormativity and the experiences of lesbian and bisexual women as social work students. Journal of Social Work Education, 41, 67-82.

Knoble, N. B., \& Linville, D. (2012). Outness and relationship satisfaction in same-gender couples. Journal of Marital and Family Therapy, 38, 330-339.

Lark, J. S., \& Croteau, J. M. (1998). Lesbian, gay, and bisexual doctoral students' mentoring relationships with faculty in counseling psychology: A qualitative study. The Counseling Psychologist, 26, 754-776.

LaSala, M. C. (2000). Lesbians, gay men, and their parents: Family therapy for the coming-out crisis. Family Process, 39, 67-81.

Lipka, S. (2011). For gay students, more room on campuses. Chronicle of Higher Education. Retrieved from www.lexisnexis.com/hottopics/lnacademic

Logie, C., Bridge, T. J., \& Bridge, P. D. (2007). Evaluating the phobias, attitudes, and cultural competence of master of social work students toward the LGBT populations. Journal of Homosexuality, 53, 201-221.

Longerbeam, S. D., Inkelas, K. K., Johnson, D. R., \& Lee, Z. S. (2007). Lesbian, gay, and bisexual college student experiences: An exploratory study. Journal of College Student Development, 48, $215-230$.

Martin, J. I., Messinger, L., Kull, R., Holmes, J., Bermudez, F., \& Sommer, S. (2009). Study of LGBT issues in social work. Council on Social Work Education-LAMBDA Legal, 1-30. Retrieved from http://www.cswe.org/File.aspx?id=25678

Messinger, L. (2004). Out in the field: Gay and lesbian social work students' experiences in field placement. Journal of Social Work Education, 40, 187-204.

Messinger, L. (2011). A qualitative analysis of faculty advocacy on LGBT issues on campus. Journal of Homosexuality, 58, 1281-1305.

Meyer, I. H. (1995). Minority stress and mental health in gay men. Journal of Health and Social Behavior, 36, March, 38-56.

Mohr, R. D. (1992). Gay ideas: Outing and other controversies. Boston, MA: Beacon.

Moradi, B., Wiseman, M. C., Deblaere, C., Goodman, M. B., Sarkees, A., Brewster, M. E., \& Huang, Y.-P. (2010). LGB of Color and white individuals' perceptions of heterosexist Stigma, internalized homophobia, and outness: Comparisons of levels and links. The Counseling Psychologist, 38, 397-424.

Morris, J. F., Waldo, C. R., \& Rothblum, E. D. (2001). A model of predictors and outcomes of outness among lesbian and bisexual women. The American Journal of Orthopsychiatry, 71, 61-71. 
Ragins, B. R., Singh, R., \& Cornwell, J. M. (2007). Making the invisible visible: Fear and disclosure of sexual orientation at work. Journal of Applied Psychology, 92, 1103-1118.

Rankin, S. R. (2003). Campus climate for LGBT people: A national perspective. New York, NY: National Gay and Lesbian Task Force Policy Institute. Retrieved from http://www.thetaskforce.org/ downloads/reports/reports/CampusClimate.pdf .

Rankin, S. R. (2005). Campus climates for sexual minorities. New Directions for Student Services, 2005, 17-23.

Rasmussen, M. L. (2004). The problem of coming out. Theory into Practice, 43, 144-150.

Rhoads, R. A. (1995). Learning from the coming-out experiences of college males. Journal of College Student Development, 36, 67.

Rhoads, R. A. (1997). Implications of the growing visibility of gay and bisexual male students on campus. NASPA Journal, 34, 275-286.

Savin-Williams, R. C., \& Diamond, L. M. (2000). Sexual identity trajectories among sexual-minority youths: Gender comparisons. Archives of Sexual Behavior, 29, 607-627.

Stevens, R. A. (2004). Understanding gay identity development within the college environment. Journal of College Student Development, 45, 185-206.

Taylor, Y. (2009). Complexities and complications: Intersections of class and sexuality. Journal of Lesbian Studies, 13, 189-203.

Troiden, R. R. (1989). The formation of homosexual identities. Journal of Homosexuality, 17, 43-74.

Troiden, R. R. (1993). The formation of homosexual identities. In L. D. Garnets \& D. C. Kimmel (Eds.), Psychological perspectives on lesbian and gay male experiences (pp. 191-217). New York: Columbia University Press.

Van Den Bergh, N., \& Crisp, C. (2004). Defining culturally competent practice with sexual minorities: Implications for social work education and practice. Journal of Social Work Education, 40, 221-238.

Vaughan, M. D., \& Waehler, C. A. (2010). Coming out growth: Conceptualizing and measuring stress-related growth associated with coming out to others as a sexual minority. Journal of Adult Development, 17, 94-109.

Waldo, C. R. (1998). Out on campus: Sexual orientation and academic climate in a university context. American Journal of Community Psychology, 26, 745-774.

Waldo, C. R. (1999). Working in a majority context: A structural model of heterosexism as minority stress in the workplace. Journal of Counseling Psychology, 46, 218-232.

Westbrook, L. (2009). Where the women aren't: Gender differences in the use of LGBT resources on college campuses. Journal of LGBT Youth, 6, 369-394.

Zemsky, B., \& Sanlo, R. L. (2005). Do policies matter? In R. L. Sanlo (Ed.), Gender identity and sexual orientation: Research, policy, and personal perspectives: New directions for student services, 111 (pp. 7-15). San Francisco, CA: Jossey-Bass. 